\title{
1 A Lay Definition of Grace: a Quantitative and Qualitative Content Analysis
}

4 Grace is a central theme in religious traditions but receives only recently attention 5

\section{Abstract} by psychologists. Conceptualizations of grace seems predominantly constructed within theological and theoretical frameworks, whereas these conceptualizations may be poorly aligned with the definitions of grace of lay persons.

This study clarifies the concept of grace and creates a bottom-up definition, based on the understanding of non-experts in a secularized society. A total of 456 Belgian adults $(64 \%$ female, mean age $=50.04)$ provided descriptions of grace in an online survey.

A multidisciplinary coding team conducted quantitative and qualitative content analysis (Nvivo). The following themes and categories emerged (1) virtuous qualities: grace is recognized in a multitude of good qualities with forgiveness as the ultimate example; (2) extra-ordinary gift: grace is something you receive unmerited, the nature of the giving goes beyond mere fair exchange; (3) transcendent and immanent setting: grace is encountered in the realm of the divine as well as in human relationships and daily life; (4) profound experience: the giving and receiving of grace entails an articulated personal involvement leading to new beginnings and freedom and (5) profound feelings: the experience of grace is accompanied with positive feelings and states often preceded by negative feelings and states.

Distribution of categories by respondent's age, gender and religiosity showed a robustness of underlying characteristics in the definition of grace. However, significant group differences are found: believing and older participants described more often extra-ordinary and transcendent characteristics, whereas non-believers used more referrals to faults and forgiveness. Believing people used more positive feelings and women used more virtuous qualities in describing grace.

The importance of further investigating the psychological dynamics of grace and its capacity for enhancing well-being is highlighted. 
Current positive psychological research addresses many concepts which were originally embedded in ancient cultural and religious traditions ( e.g. humility, gratitude and forgiveness). Within a positive psychological framework, these concepts are perceived as potential strengths or sources for positive functioning and positive development, studied from a psychological perspective and implemented in empirical studies. The current article is the first step in exploring whether grace could also be part of these evidence-based character strengths and/or sources of coping.

Current conceptualizations of grace are nearly always based on theoretical models and are predominantly developed within a theological or ethical philosophical framework (Emmons et al., 2017). Little knowledge is therefore available on how individuals themselves perceive or define grace. In this article, we will discuss grace as it is understood in a society (Belgium) mainly influenced by Christianity (Catholicism) in the past and by secularized views in the present.

Along with historical, philosophical and theological views, people have their own perceptions of grace. These lay-interpretations and definitions are important to grasp. If psychological researchers want to credibly investigate grace, it is crucial to understand and incorporate these lay-interpretations and definitions. These lay understandings are not only essential to instruct further research and scale development but may also contribute to the understanding of the possible impact of grace in human life. Our aim therefore is to provide a bottom-up conceptualization of grace by lay persons themselves.

In framing our research we first give a brief overview of Christian conceptualizations of grace, secondly present the scarce empirical and psychometric research available about grace and in sum conclude with psychological reflections about the potential relevance of grace.

\section{Christian perspectives on grace}

Grace is a crucial concept in multiple religious traditions, particularly in Judaism, Christianity and Islam, but corresponding concepts are found in various

31 branches of Buddhism and Hinduism as well (Betz, Browing, Janowski, Bernd \&

32 Jüngel, 2007 \& Ward, 1998). More specific in Vedanta Hinduism, God is also seen as 
1 abundant in mercy with infinite generosity and in Vaishnava Hinduism, the grace of

2 God can be enjoyed by surrendering the self to Lord Vishnu (Emmons, Hill, Barrett \&

3 Kapic, 2017; Frenz, 1975 and Gowack \& Valle, 1998). As the cultural context of the current investigation is mainly influenced by Christianity, we give a more elaborate overview of the development of grace in this tradition. The Dutch theologian Versteegen (2013) has provided a thorough overview of the theological development of grace in Christian history, from which we briefly discuss key aspects and turning points.

Until the middle of the last century grace (Lt. gratia, Gr. charis) was in general described as a supernatural gift of God to intellectual creatures (persons, angels) for their eternal salvation (Catholic Encyclopedia, 1909). An important division that is made in this classic understanding of grace is between uncreated grace- God Himself - and created grace. The emphasis is on the total gratuity of grace with God as the ultimate source and purpose (New catholic encyclopedia, 1967). In this vein, grace summarizes the essence of God's relationship with humans (Lacoste, Riaudel \& Beauchamp, 2007).

In the mid-twentieth century, the church was challenged in its relation to modern times. Different theologians began to question the formalization of grace in objective categories. A common theme in this modern theological discourse was the need to capture the lived relation between human and divine nature. Important contributors to this debate of how the theology of grace can be linked with real life were, from a 21 Catholic perspective, De Lubac, Rahner and Schillebeeckx. De Lubac (1946) strived to connect human and divine history, to make a linkage between belief and the concrete world by accentuating the natural longing to God, following Thomas Aquinas' concept of 'desiderium naturale'. Rahner (1954) even went a step further by stressing that human nature is in itself already gifted by grace, expressed in the concept of the 'supernatural existential'. Schillebeeckx (1977) confirmed Rahner's theology and deepened the understanding of the relationship between the gratuity of God's grace and the autonomy and responsibility of humans. He emphasized how the gift of grace manifests itself in our own human history, in the encounter with fellow people. The view of Schillebeeckx (1977) highlights an important point, namely that grace in theology is not merely a divine act, but also something people can offer to each other. This was already present in classic theology, but was placed more and more in the forefront in, for example, liberation theology, which arose under influence of Vatican II. 
1 The focus here was specifically not on the theology but on the praxis of grace, the 2 praxis of liberation.

A feminist view on grace is given by different Catholic, Protestant as well as

4 Jewish theologians like Brock, Daly, Grey, Harrison, Hilkert, Hinsdale, Murphy,

5 Niebuhr, Plaskow, Ross, Saiving and Welch. They marked the relationally and

6 transforming power of grace. They highlight the mutual relationship between humans

7 and God and show how grace can be found in the community, in the connections

8 between people. Feminist theologians made the experience of grace in daily life more

9 visible on a very tangible way.

10 Since the nineties theologies and discourses about grace began to differ more 11 and more. The essays and explanations about grace can no longer be summarized under 12 a few 'big stories'. Where theology used to consist of clear frameworks and clarity in 13 dogmas and expert views from a top-down position, the theology of grace is nowadays 14 scattered. The aforementioned collection of different theologian narratives illustrates the more subjective and individualistic searching for theological interpretation and meaning. Discussions are about how the divine and the human can interact and connect which each other without losing divinity and without losing touch with real life, but the core idea of grace as a divine gift that brings a person into salvation remains (Basset, 2013). Summarized by Graves (2017, p.. 305):

"Depending upon one's tradition, the salvific change may occur within the divine relationship (justification) or within the person (sanctification). Grace may occur in particular times and places within a person (e.g., prevenient grace), through all proper administrations of certain visible rituals (sacraments), or as a general aspect

\section{Empirical outlook on grace}

In contrast to this long theological and philosophical history, the first empirical studies about grace began only in the eighties and are rooted within a psychological 28 framework. Watson, Morris, and Hood (1988a, 1988b) worked on an operationalization of religiosity, including measures relating to sin and grace, in order to clarify the relation between self-esteem and religiosity. In further research they demonstrated the interrelatedness between beliefs dealing with grace and guilt on the one hand, and internal states of awareness, consciousness, and depression on the other (Watson, Hood, 
1 Morris \& Hall, 1988a and 1988b). In addition to the studies focusing on the

2 intrapersonal level, grace has also been investigated as a component in the relational

3 reconciliation cycle (Sells, Beckenbach, \& Patrick, 2009). In this context, grace is

4 understood as an important factor in breaking the pain-defense cycle within human

5 relations. Patrick, Beckenbach, Sells, \& Reardon (2013) support that instead of taking

6 up a defensive or protective position to pain, offering grace can redirect people to pro-

7 social behavior. Another study found that self-reported grace (conceptualized as the

8 experience of God as empowering agent in their life) could be experimentally increased

9 through sermons, small-group study programs and personal grace practices and was

10 able to increase trait self-forgiveness but not marital satisfaction (Bufford, McMinn,

11 Moody \& Geczy-Haskins, 2017).

12 Next to psychological empirical studies about grace, there is also a growing

13 interest in empirical studies about theological concepts from the perspective of

14 academic theology itself. One example is the study of 'ordinary theology' (Astley,

15 2002). This refers to empirical theological research about beliefs of 'ordinary' persons

16 or non-experts, complementing classical theological reflections on written, authoritarian

17 sources such as the bible or views from academic theologians or church leaders.

18 However, grace has received remarkably little empirical attention from a theological

19 perspective. A notable exception is found in Versteegen (2013), who studied the lived

20 experience of grace of non-expert women, based on qualitative research (in-depth

21 interviews).

From a psychological perspective the interest for psychometrical reliable instruments about grace increased. Different scales were developed. They are all based on a Christian theology of grace with specific attention to the justifying and sanctifying power of grace in life. The aim of the first Grace Scale was to capture the experience and expression of grace, both divine and human (Payton, Spradlin \& Bufford, 2000 and

27 Spradlin, 2002). The Richmont Grace Scale focused on human responses to divine 28 grace (Blackburn, Sisemore, Smith \& Re, 2012; and Watson, Chen, \& Sisemore, 2011).

29 The Amazing Grace Scale emphasizes on the feelings and (re)cognitions about God's 30 gracious deeds (Bassett \& the Roberts Wesleyan College Psychology Research Group, 31 2013). Based on the previous scales, Bufford, Sissemore, and Blackburn (2016) 32 proposed the Dimensions of Grace Scale with five factors namely experiencing God's 33 Grace, Costly Grace, Grace to Self, Grace from Others, and Grace to Others. 
An important limitation is that almost all of these studies were conducted in a

2 Christian context (church communities, Christian students, pastoral counseling), mostly

3 in evangelical-protestant contexts. Belgium, in contrary, has a strong Catholic roots still

4 visible in school systems, trade unions and health insurance companies. At the same

5 time, Belgium is secularizing which is visible in for example, very liberal legislation on

6 topics of LGTB rights, abortion and euthanasia, as well in the interpretation of their

7 catholic identity. Belgium can in this vein serve as a test case to study grace in

8 contemporary European societies where grace has been part of the cultural religious

9 tradition but where religious manifestations are currently no longer visible in the public

10 social narrative.

\section{Psychological reflections on grace}

Besides this growth of empirical studies, several researchers and practitioners reflected in a more fundamental as well as in a practice-oriented way on the key elements of grace which are important for psychological functioning (Dudley, 1995; Graves, 2014; Graves, 2017; McMinn, Ruiz, Marx, Wright, \& Gilbert, 2006 and McMinn, 2010). In this regard Emmons, Hill, Barrett, and Kapic (2017) described grace as a vital psychological need in line with the concept of unconditional acceptance of Rogers (1951). They defined grace as the "gift of acceptance given unconditionally and voluntarily to an undeserving person by an unobliged giver" ( p.277). They call attention to three important characteristics of grace besides the 'unconditional acceptance' aspect: (1) a giving, happening in a relational/social context (giver/receiver); (2) voluntarily, the agent acts under no obligation and (3) the recipient is undeserving which means that the agent intentionally violates the social obligation. In line with Thomas Aquinas, Graves (2017, p. 305) considers grace as a

26 "habitus, an active state of moral or intellectual character inclining the person toward certain actions and emotions." In this regard, Graves broadens the concept of grace, going beyond the relational aspect. He invites psychologists to identify and explain how decision-making and emotional regulation can be informed and developed by habits guided by the virtue of grace. Graves draws attention to healthy psychological structures which underpin virtue development and spiritual formation as well as the narrative self 
1 and personal identity. In this way, he focuses and challenges the collaboration between

2 theology and positive psychology .

3

4

This idea of grace as purifying and strengthening the human person in psychological development is in line with both old and current literature on grace as a transformative power (Bronte \& Wade, 2012; Cunningham, 2003; James, 1902; Marks, 2010; Versteegen, 2013 and Wahking, 1992). Both case studies and empirical studies illustrate how the experience of grace and the search for grace is seen as an important component in personal development.

In sum, the aforementioned studies and these psychologists underwrite the idea that grace can be a positive energizing source in life (Meissner, 1966): it is hypothesized that grace can help people with their character development (Graves, 2016), demonstrated as being a source of sustaining connectedness (Sells, Beckenbach, \& Patrick, 2009), linked with subjective well-being (Watson et al., 1988a and 1988b) and it might be a source to fulfill universal human needs (Emmons et al., 2017). However, in order to address this call for further research into the psychology of grace, it is first needed to gain insight in how lay persons in Western secularized societies perceive or conceptualize the phenomenon of grace.

\section{Data collection procedure}

\section{Methods}

Sampling was designed to meet the objective of the study namely to obtain lay definitions of grace in a sample of Dutch speaking Belgian adults anno 2019. A questionnaire was set up in online format (using Lime Websurvey, KU Leuven). A convenience sampling approach was used inviting a broad range of participants through various personal as well as professional channels to participate in the study (i.e., snowball sampling) (Gentles, Charles, Ploeg \& McKibbon, 2015). Communication went by email and internet fora and was accompanied with a thorough information letter.

Sampling became purposeful (with regard to age and religiosity) during the data collection process when preliminary analyses showed an under-representation of specific groups (i.e., young adults, non-religious individuals) (Coyne, 1997). Additional sampling in these under-represented groups resulted in a more representative final 
sample.

\section{Participants}

The original sample consisted of 523 participants. However, 52 participants did not fulfill the inclusion criterion with regard to Belgian nationality, 14 did not have Dutch as their mother tongue, and one participant was younger than 18. After excluding these participants, a final sample of 456 adults was obtained (mean age $=50.04 ; S D=$ 18.335; age range between 18 - 93 year, 64\% women). Civic state was mixed, with $64 \%$ in a relationship, $22 \%$ single, $6.5 \%$ divorced, $3 \%$ widowed and $4.4 \%$ otherwise. Educational level was mixed with $2.2 \%$ lower secondary education, $10.3 \%$ higher secondary education, $29 \%$ college degrees, $45 \%$ university degrees and $13.4 \%$ missings. Highly educated individuals were overrepresented in our sample considering the fact that $32.2 \%$ of the population in Belgium has a higher (college or university) degree (Statbel, 2017). With regard to the level of religious activity, $37.1 \%$ of the participants reported weekly church attendance, $9.9 \%$ monthly, $23 \%$ only for celebrations or once every few years and $8.8 \%$ reported that they never attend religious activities. Regarding worldview, $18.3 \%$ identified as Christian, $51.1 \%$ as Catholic, 9.2\% as Humanistic and $10.3 \%$ as other. Compared to a representative Flemish population wherein 47,9\% indicate not having a religious belief, non-believers are underrepresented in our sample (Corijn, 2017). In addition, with regard to the religious descriptives, a considerable amount of data was missing, more precisely $11.6 \%$ on worldview and $21 \%$ on frequency of religious activities. This might be due to the location of these questions in the survey (i.e., at the end of the survey).

\section{Instruments}

Open question on Grace. Based on similar research on lay definitions (see Beverly \& James, 1991 on the definition of love and Fehr \& Russell, 1984 on the definition of emotion) one open question was asked that invited participants to provide a written description of the concept of grace within a timeframe of maximum 3 minutes (see appendix 1 for the complete instruction and original Dutch specification). The core of the instruction was as followed: “Please list as many characteristics of grace as come to mind. These characteristics can be about typical elements, parts, facets, feelings, ideas or behaviors, anything that 
1 can help to define GRACE." This question was always asked first, so as not to prime participants with the other measures.

3 Similarity assessment of common virtues. Based on prototypical rating studies (e.g., 4 Elshout, Nelissen, \& Van Beest, 2015; Beverley \& James, 1991; Fehr,1988; Fehr \& 5 Sprecher, 2009; Ruch \& Prover, 2015), a similarity rating test was added in which 6 participants were asked to compare grace with other virtues and quantify the overlap:

7 'How similar do you perceive these terms to grace?' with answer possibilities ranging

8 from $0 \%$ (no overlap) to $100 \%$ (complete overlap).

9 We choose for this virtue rating because virtue and grace seems to have a complex but 10 old relationship (Graves, 2017 and Wetzel, 1992). But to our knowledge, no research is 11 available on how different virtues and grace are related in a semantic way. Participants answered by using a slider marked with zero at the beginning and hundred at the end. A

13 list of 62 virtues was offered. This list was constructed based on the six virtues and 24 14 character strengths from the VIA-project (Ruch, \& Proyer, 2015), the three theological 15 virtues (faith, hope, and love), the intellectual and moral virtues of the second part of 16 the Summa Theologica (1265-1274/ 1947) by Thomas Aquinas, the virtues mentioned 17 in the Catholic Catechismus $(1997,2008)$ namely, the seven traditional virtues, seven 18 gifts and seven fruits of the Spirit originating from prominent early church fathers. After elimination of overlapping virtues, 62 virtues were retained (see appendix 2).

In addition, socio-demographic information (age, gender, educational level, civic state) as well as religious information (worldview, centrality of faith, and frequency of religious activities) were gathered.

\section{Research Design}

Based on a constructivistic position we acknowledge that knowledge may be uncovered by unpacking individual interpretations and experiences (Charmaz, 2014). Content analysis - both quantitative and qualitative - was chosen as data analysis method because of its objective and systematic way of describing phenomena.

28 Combined quantitative and qualitative analysis is useful when conducting knowledge29 building and theory-generating research on a more abstract level (Carmichael \& 30 Cunningham, 2017; Egberg, Wiberg, Lundman \& Graneheim, 2013; Finfgeld-Connett, 2014; Gokcen, Hefferon \& Attree, 2012). Since available bottom-up theory is very scarce (see Versteegen, 2013 for an exception) and since the main focus of the study is 
1 concept development (Hsieh \& Shannon, 2005), combined quantitative and qualitative

2 analysis seemed the best fitting method (Schreier, 2012; Vaismoradi, Turunen, \&

3 Bondas, 2013 and Zhang \& Wildemuth, 2009). This study was preregistered at the

4 Open Science Framework (https://osf.io/jb2vh) and approved by the ethics committee of

5 KU Leuven (SMEC ID G- 201805 1237).

\section{Analytic Strategy}

$7 \quad$ Since we worked primarily with written descriptions about grace, qualitative

8 data analysis is required. Iterative in its nature, a qualitative process implies that

9 researchers analyze, think and rethink their codes and categories seeking for patterns

10 who will inform them about typical instances of the phenomenon under study (Levitt et

11 al., 2018 \& Saldana, 2013). This cycle is self-correcting, as when new insights and data

12 come into light, coding will be corrected and refined. Furthermore, to improve validity,

13 triangulation of methods, data, and investigators (by means of a multidisciplinary

14 coding team) is embedded. (Carter, Bryant-Lukosius, DiCenso, Blythe \& Neville, 2014;

15 Denzin, 1978; Jick, 1979, Johnson, 1997; Golafshani, 2003). starts from raw idiosyncratic data (written definitions of grace) to more abstracted themes and more general theoretical propositions (building blocks for a lay taxonomy of grace) in a step by step process. Our data analysis process consisted of a summative quantitative content analysis followed by a qualitative content analysis. To enhance the validity, the categories found were contrasted with quantitative data (triangulation) and multidisciplinary expert checking was done during the process and on tilting moments

27 (Krippendorff, 2003; Schreier, 2012; Weber, 1990; Wilkinson \& Birmingham, 2003).

28 After agreement on the categories, group differences group differences were assessed by using the Pearson's chi-squared test based on age, gender, worldview and religious activity (Pearson, 1900). We corrected for multiple testing by using a false discovery rate method (FDR), more specifically, the Benjamini-Hochberg procedure (Hochberg \&

32 Benjamini, 1990). 


\section{Preparing a list of keywords based on quantitative content analysis}

3 In a first step, all keywords were counted. Since keywords were defined as any word or

4 phrase used to convey a substantial idea; virtually all words were included in the data

5 analysis, leaving only prepositions (e.g. in, on) and some pronouns (e.g. he, she)

6 excluded. All other words were handled as separate keywords, also the synonyms. Next,

7 summative quantitative content analysis was performed in Nvivo 12. The word count

8 query delivered us a list of 2635 unique words, not a single word was used by everyone

9 (Chiang-Hanisko, Newman, Dyess, Piyakong, \& Liehr, 2016). Individual keyword

10 frequencies ranged from one to 162 across all counts. In order to balance the

11 maximization of data input and the minimization of extremely idiosyncratic results, a

12 cut-off of three was chosen: words were included in the analysis if they were

13 mentioned at least three times by different participants (Gocken, Hefferon \& Attree,

14 2012; Elshout, Nelissen \& Van Beest, 2015). 2015 words were only mentioned twice or 15 once and thus left out of the analysis.

16 ---FIG2---

17 Figure 2 visualizes the analytic process with the intermediate steps. After this 18 quantitative preparation of the data, 620 keywords were left to analyze. The top ten of 19 the most used words were forgiveness (162), God (106), life (75), love (72), present 20 (63), someone (59), gift (42), received (53), power (44) and unearned (44). All codes 21 were rearranged based on equal syntax (e.g., good and goodness) and similar semantics 22 (e.g., to get and to receive) into sub-codes and overarching codes (e.g., code 23 'compassion' with sub-codes 'merciful'; 'compassionate'; 'forbearing'). Given the 24 multitude of different words used to express ideas, we listed the top five codes with the 25 most used words for each category in Table 1 . Arriving here at 422 codes, a qualitative 26 content analysis was started.

27 
1 Clustering of codes into categories and themes based on qualitative content analysis

3 Triangulation of clustering by means of single experts and multidisciplinary

4 checking. Because our aim was to construct a bottom-up conceptualisation of

5 grace, a combination of single inductive coding (first author) and

6 multidisciplinary expert checking (co-authors), was used in order not to rely on

7 existing theories and expert views. During the clustering process from codes to

8 categories, the codes were considered in their broader text context by reading the

9 total descriptions.

10 An example of this contextual checking typical for content analysis is the 11 categorization of the code 'life': we needed the context of the description to 12 discern if life was used as new life (category 'new beginning') or life as 13 circumstances (category 'daily life'). After multidisciplinary checking with 14 experts from theology, clinical psychology, client centered psychotherapy, 15 developmental psychology, and philosophy, agreement was found for a 16 meaningful clustering of all codes into 11 categories. In the whole coding and 17 recoding process, all disagreements were resolved by discussion until complete 18 agreement. Table 1 gives an overview of the resulting categories emerging out of 19 our data. We illustrate each category with an example quote in table 2 in order to 20 make the different categories more tangible.

21 Triangulation of clustering by means of comparison to quantitative virtue data. 22 To maximize validity and trustworthiness of our results, the obtained 23 categories were contrasted with the data obtained from the virtue-ratings.

24 Participants were asked to indicate how similar or distinct 63 classical virtues 25 were from grace. First, we calculated the mean per virtue and the grand mean across all virtues. To test which virtues outweighed the other virtues, we calculated z-scores for each virtue based on the grand mean. The virtues that positively differed more and less than one standard deviation from the overall mean are presented in Table 3. These virtues were perceived by participants as

30 most and least similar to grace. 
The top virtue ratings (quantitative results) strongly corresponded to the top

2 content codings (qualitative results), visible when comparing the codes of table 1 with

3 the virtues in table 2 . These are strong illustration of convergent validity. Virtues rated

4 very different of grace were for example linked to attuning to a larger whole or to the

5 domain of sexuality. Furthermore, vengeance ${ }^{1}$ was rated the most different from grace

$6 \quad(\mathrm{z}=-2.50)$ which also confirms the top content codings in a divergent manner.

\section{$7 \quad$ Exploring the categories between different groups}

To explore the lay understanding of grace in regard to the personal, contextual and religious context, we proceeded with complementary analyses. We are interested in potential differences in descriptions between groups based on their age, gender, worldview and religious activity. We made four different crosstabs with the query function of Nvivo pro 12: the rows are the eleven categories as shown in table 1 and the columns represent the groups to compare, the cells display how many times the corresponding group (column) referred in their definitions to the accompanying category (row) (see also table 4-7). These secondary analyses point out two important aspects. First, all categories and themes were mentioned $(\min 5 \%-\max 73 \%)$ by all the different groups. This shows the robustness of the categories across secular as well as believing participants. Secondly, when we contrast the relative use of the different categories per group between groups, we did find significant differences. To assess how the different groups lay their own accents in the defining of grace, we used the Pearson's chi-squared test. Table 4 to 7 present the results and the corresponding significance levels. Age (table 4). Participants of 40 years and older tended to describe grace with more characteristics within the extra-ordinary and transcendent realm.

Gender (table 5). Female participants used more good qualities in describing grace compared to male participants. Worldview (table 6). With regard to believing, participants who identified themselves as believing in a transcendent reality used more frequently words of the extra-ordinary and transcendent category when describing grace, and referred more to positive feelings. Non-believers on the other hand used more words referring to faults and

\footnotetext{
${ }^{1}$ Taking vengeance for injuries or wrongs, act in order that justice may be done. Not to be confused with revenge, a more personal action to avenge usually by retaliating.
} 
1 forgiveness.

2 Religious activity (table 7). Religiously active participants (at least monthly attendances

3 to mass and/or religious meetings) understood grace more in terms out of the domain of

4 the extra-ordinary, transcendent, positive and negative feelings, giving and receiving.

5 Non or very limited religiously active participants (visiting religious places less than

6 once a year) stressed comparatively more the forgiving of faults aspect of grace.

In sum, over all the groups the primacy of the virtuous qualities with a strong

8 emphasis on forgiveness is clearly reaffirmed. This is also true for the overall

9 importance attached to the relational nature regarding the giving and receiving part of

10 grace and the reality of enactment of grace between people. But age, gender, worldview

11 and the level of religious activity are clearly related with the kind of descriptions people

12 give about their understanding of grace. These findings support the view that the

13 understanding of grace is dependent on one's personal context and background.

Discussion society. Reviewing the emerged eleven categories, we concluded together that one possible way of arranging them into a comprehensible whole was to cluster them according to prototypical reflection questions about experiences: "What? Where? With whom? How? What are the consequences?". We chose to summarize our findings into characteristics (concerning 'the what'), relational setting (concerning 'the where and with whom'), and transforming experience (concerning 'the how and the consequences').

The resulting six themes and three theoretical building blocks are presented in table 1 and figure 3.

In arranging the data this way, building blocks of a lay definition about grace are (a) key characteristics of grace: virtuous qualities - especially forgiveness - and the fact that grace is freely given to an undeserving recipient, grace is of an extra-ordinary nature going beyond mere fair exchange; (b) the setting where people experience grace 
1 can be both in encounters and in circumstances, the agent of grace can be both human or

2 divine; (c) the consequences of grace as leading to freedom, new beginnings, and

3 personal growth. Grace seems to be a multifaceted concept that can be recognized and

4 experienced to a greater or lesser extent in someone's life.

In a classical definition concepts are defined by a set of individually necessary

6 and jointly sufficient criterial attributes (Rosch, 1973). The number of different

7 keywords and the fact that not one single word is mentioned by everyone indicates that

8 grace has a more complex nature than a classical concept. The number of different

9 understandings, situations, features and experiences may support the view that grace

10 instead of a concept is actually linguistically speaking a category bringing together a

11 diverse collection of similar but not equal experiences under a single heading.

12 Finally, we will comment on the building blocks while illustrating them with

13 some extra-ordinary quotes of our participants capturing and bringing together in a

14 beautiful way the many lists of features and shorter descriptions of the other

15 participants.

\section{Characteristics of grace}

Our findings suggest that the face of grace is recognized in the encounter with

18 different kinds of virtues. Forgiveness and compassion are mentioned most often. Grace

19 is especially recognized when a fault is forgiven or in legal situations when the deserved

20 punishment is not executed or is withdrawn.

21 Every forgiveness is an act of grace. But not every form of offering grace is an act of

22 forgiveness. Our findings illustrate that grace can be found in many other forms and

23 experiences than forgiveness. Comparing our findings with the Values in Action

24 classification from Peterson and Seligman (2004), grace seems especially associated

25 with the strengths of forgiveness, kindness, love, and humanity. These are virtues

26 concerning connections and relationships. This finding aligns well with the second

27 characteristic of extra-ordinary giving and receiving. Echoing Emmons et al. (2017),

28 participants confirm the relational definition of grace as presented in terms of the

29 unconditional acceptance (acceptance was the seven most frequently coded quality), 
1 grace as a gift, the voluntary character of the giving by the agent and the undeserving

2 position of the recipient.

A third characteristic was the extra-ordinary. This category seems to indicate that grace does not follow the economical rules, it goes beyond these rules, it goes beyond the expected, the ordinary. Our findings are in line with the anthropologists Peristiany and Pitt-Rivers (2005) who wrote about the relationship of honor and grace and illuminate that grace structures relationships by a different kind of reciprocity beyond mere fair exchange. Here again, the 'gratuitousness' of the gift of grace is central. This point of view is also in line with the ancient meaning of 'charis' in Greek poetry referring - besides the meaning of beauty and what can give joy - to a special favor from someone higher in rank (MacLachlan,1993; Spuybroeck, 2014). In the words of our participants:

"Grace is a gift, something positive, a happy coincidence that is not coincidental. Grace pushes the boundaries. Grace lets the divine come in. Grace is not earned, grace is achieved without compensation. There is no question of quid pro quo." or "The law and justice are violated if someone is released by grace." Participants stress the undeserving part of the receiver. This refers to the classical and theological idea that you are never in a position to claim grace. It seems you can be open to receive it and the only possible answer is being grateful and maybe more willing to enact grace yourself to other human beings. Significant to note in this regard is that gratitude and grace stem from the same Latin word gratia. Gratitude itself was also an important code together with hope and spirituality. Looking again at the VIAclassification, these three character strengths tap into the virtue of transcendence, which forms connections to the larger universe and meaning in life. Given the strong semantical link between grace and different kinds of virtues and the idea of grace as a category clustering different virtues together, it may be a promising avenue for future research to examine grace as a possible undergirding mechanism emboldening virtuousness in life (Luna, Van Tongeren \& Witvliet, 2017).

\section{Relational structure}

Based on our data we argue that grace concerns not solely the relation between the human and the divine but also extra-ordinary gifts between humans themselves, beyond mere reciprocity. The descriptions in our data showed that grace is received 
1 from a human or divine agent or in certain circumstances. However, in all three

2 occasions, the receiver needs to open herself up to something/someone, to receive

3 something bigger than herself: "Grace is two-fold, grace includes giving and receiving.

4 For grace you must be at least two." or "You will never find grace if you fold back on

5 yourself, stay in your own world."

6 Besides the human and divine enactments of grace, participants mentioned the

7 aspect of hierarchy and power in the relationship where grace can be given.

8 "A condition for grace is empathy, gentleness in judgment, forgiveness, relativizing,

9 giving new beginnings. When talking about grace, however, there is also a part on

10 'power' and hierarchy in which the giver of grace is in the upper position and the

11 receiver in the downward position. Grace seems to me something typically human in

12 which judgment is not formed by an algorithm but by a complex interaction between

13 justice and compassion."

14 The present study confirms the view of contemporary theology that grace can be 15 experienced in very different contexts. Participants described small ordinary immanent 16 things, everyday moments and encounters that strike them as graceful e.g., an empathic

17 listener, receiving material help, feeling appreciated, graceful sensory perceptions,

18 happiness,... Besides the immanent, grace is also described as an exceptional

19 coincidence of circumstances experienced as a divine gift coming from a transcendent

20 reality or the gift of Life itself. Religious or spiritual participants address more potential 21 domains of experiencing grace (immanent and transcendent reality) and recognise being 22 the recipient of human and/or divine agents, whereas non-believing participants focus

23 more on the receiving of grace by other humans in case of transgressions and happy 24 luck in certain situations.

\section{Transforming experience of growth}

Lay people define grace as an awe-inspiring undeserved gift leading to freedom and growth. So grace is not only an unconditional, undeserved gift, it concerns also the consequences. The effect of grace lingers in the aftermath of an experience full of grace.

In brief, current findings suggest that giving grace asks a certain personal involvement, an attitude, courage, and wisdom, a decision beyond mere logic. On the receiving end, grace demands a certain awareness and openness that you can't make it all by yourself. Living in the face of grace also means to understand and grasp your 
1 ultimate vulnerability and inherent connection and interdependence with other living

2 beings and/or with God.

3

Furthermore our data showed that the experience of grace is accompanied by a wide range of profound feelings. Negative feelings and/or states following a fierce argument, psychological suffering, sense of sin trigger the search for a way out. A new range of positive feelings then arise from the tipping point created by grace, such as happiness, joy, liberation, and peace. Feelings affect the whole person and are a strong motivator in decision-making (Greifeneder, Bless \& Pham, 2011). Cognition (profound involvement) and affect (profound feelings) work together in the dynamics of social and personal relationships (Planalp \& Fitness,1999). The present study supports the view as presented in the introduction that grace is seen as a transformative, growth experience. Summarized by a participant quote:

"Grace is an unexpected coincidence, comes from a higher consciousness, embraces your entire being, is soft and loving in feeling. Grace is deeply transforming for 5 yourself and for your life. Grace is being touched, being touched by the 'higher'. It is 6 an overall experience in thinking, feeling, being. Grace communicates to others, your 7 environment. It is 'divine' as an experience and brings you more IN to your own 8 Divinity. It is in resonance with something in yourself. It raises you up, reveals (it 9 gives birth and opens). It's non-linear, not logical."

\section{Limitations}

There were three main limitations in this study that should be acknowledged. First, the relative overrepresentation of believing participants was a main concern. We presume that this was a side effect of the auto-selection by participants interested in the topic of grace. We took this skewed distribution into account by doing complementary analyses revealing the robustness of our definition by showing that all categories were mentioned in all groups and enriching our conceptualization by indicating significant differences in focus between groups of participants. Furthermore, in Belgium, even the subgroup identifying as Christian is part of a predominantly secularized context. The catholic faith is our cultural state religion which means important milestones are celebrated with catholic rituals and traditions. A large part of our participants indicating being Christian or Catholic are in fact cultural Christians. 
The second point of attention is the fact that (qualitative) analyses are always

2 one possible way of structuring and understanding the data. We are aware of the fact that there are good arguments to place some codes into other categories or themes. Also important to note in this regard is the fact that the relational nature of grace is woven through all themes. The aspect of hierarchy -here treated under relational structure- is also an important aspect of the undeserved giving, mentioned by Emmons et al. (2017) in stressing the unobligated crossing of social boundaries. We chose in this matter for mutually exclusive coding in order to be able to perform also a quantitative content analysis. We tried to maximize validity and reliability of the findings by triangulation in data-analysis and by working thoroughly and transparently in all study phases.

Finally, we are aware of the fact that the connotations and use of the Dutch word for grace 'genade' are still very different from the use of 'grace' in English language. As a consequence, we had to make a trade-off between reaching a broad audience with this article by translating the codes into English and staying close to the original meaning of the Dutch descriptions. Taken together, the existing void in research about grace was more important to deal with so we opted for an internationally accessible report of our findings. After analysing, we were reassured that the language issue did not affect our research on a fundamental level given the similar domains emerging from our data in comparison with English-language research and reflections about grace.

\section{Conclusion}

22 Working with qualitative data from a large sample allowed the formulation of a

23 multi-faceted and ecological description of grace as perceived and experienced in 24 daily life. Core characteristics of our emerging lay definition about grace are virtuous qualities, undeserved receiving, transcendent and immanent sources, new beginnings and profound personal involvement and opportunity for growth.

Two main conclusions can be taken. First, the themes found in our study match partially the top-down conceptualizations as presented in the literature about the psychology of grace. To illustrate this statement, we compare the 30 subscales of the Dimensions of Grace Scale (Bufford, 2016) with our resulting themes. We highlight the parallels and differences: (1) Experiencing God's Grace

32 (e.g. "Because of God's work in my life I feel I have more self-control. My actions are more likely to be appropriate."). Our participants also mentioned the 
1 transcendent as an important context to encounter grace. This scale seems to

2 indicate some motivational power as well. This motivational part resembles our

3 findings about the personal involvement and opportunity to choose for moral

4 growth. In this regard, our participants added the experience of relational human

5 grace as inducing gratefulness and incentive to do the right thing as well; (2)

6 Costly Grace (e.g. reverse scored item “The harder I work, the more I earn God's

7 favor") mirrors the many lay statements about the extra-ordinary freely given

8 nature of grace; (3) Grace to Self (e.g. "I accept my shortcomings") Self-

9 compassion and forgiveness has not been retained as a typical category out of our

10 data ; (4) Grace from Others (e.g. "As a child I was confident that at least one of

11 my parents loved me no matter what.") resembles the receiving of forgiveness for

12 faults. but our participants placed these experiences in the present whereas all

13 items from the subscale Grace from Others direct childhood experiences and (5)

14 Grace to Others (e.g. "When offended or harmed by others I generally find it easy

15 to forgive them") assesses the tendency to forgive. Our participants defined

16 forgiveness as one favorite face of grace but grace goes beyond giving forgiveness

17 alone, it is more a form of unconditional acceptance and overall benevolence. The

18 last two subscales parallels also our findings regarding the relational structure of

19 grace with a human agent and receiver. In line with theology and contemporary

20 grace scales, our participants confirm the possibility of experiencing grace as

21 coming from God and also enacted by humans. Three emerged categories are not

22 found in existing scales about grace: (1) strongly stressed by our participants are

23 the many modes of grace identified in all kind of good qualities/ virtues; (2) the

24 experience of grace in daily life, as an empowering encounter with beauty and life

25 itself and (3) the great share of profound feelings related to grace and the

26 experienced effect of grace on emotional life as well. It seems participants

27 understand the experiential part as an important facet in the definition of grace as

28 well.

Second, our results found evidence for different conceptualizations of

30 grace based on age, gender and religiosity. This highlights the importance to be 
1 sensitive to the background of the target group in doing research, analyses and

2 interpretations.

Our bottom-up conceptualization of grace is important for the construction of

4 sound scholarly instruments as well as for the development of adequate support for

5 personal growth. The fact that our findings reside in the world of virtues strengthens the

6 call of Graves (2017) to refine and illuminate how cognitive and emotional integration

7 and regulation can be influenced by habits inspired by, for example, the virtue of grace.

8 We fully agree with the statement of Schnitker and Emmons (2017) that the psychology

9 of virtue is the ultimate ground to foster cross-disciplinary conversation, especially, we

10 argue, between positive theology and positive psychology. In line with Emmons, Hill,

11 Barrett, and Kapic (2017), we forward grace as a topic of special relevance in this field,

12 waiting to be further discovered in terms of conceptualization, measurement, related

13 concepts and connection to flourishing, well-being, and mental health.

\section{Acknowledgments}

16 We would like to thank Guido Doornberg, Em. Prof. Martin Moors, Heidi Pellens,

17 Evalyne Thauvoye and Prof. Siebrecht Van Hooren for their assistance in the data 18 analysis.

19 We would like to thank all our participants who dedicated their time and precious thoughts to share their understanding and experience in such rich descriptions about a complex topic as grace.

\section{Declaration of interest statement}

The authors declare no potential conflicts of interest with respect to the research, authorship, and/or publication of this article.

\section{Funding}

The authors are funded by an interdisciplinary seed grant from the Group Humanities and Social Sciences of the KU Leuven (Belgium) 


\section{References}

Aquinas, T. (1947). Summa Theologica, Benziger Bros. edition, Translated by Fathers of the English Dominican Province. (Original written in 1265-1274) http://www. ccel. org/ccel/aquinas/summa. html.

Astley, J. (2002). Ordinary Theology. Looking, Listening and Learning in Theology. Farnham: Ashgate.

Bassett, R.L. (2013). An Empirical Consideration of Grace and Legalism within Christian Experience. Journal of Psychology and Chrisitanity, 32(1), 43-69. https://doi.org/10.1080/0039338X.2014.906064

Bassett, R. L., \& the Roberts Wesleyan College Psychology Research Group. (2013). An empirical consideration of grace and legalism within Christian experience. Journal of Psychology and Christianity,32, 43-69.

Beckenbach, J., Patrick, S., \& Sells, J. (2010). Relationship conflict and restoration model: A preliminary exploration of concepts and therapeutic utility. Contemporary Family Therapy: An International Journal, 32, 290-301. http://dx.doi.org/10.1007/s10591-010-9117-3

Betz, D., Browning, Don S., Janowski, B., \& Jüngel, E. (2007). Religion past \& present: Encyclopedia of theology and religion. Leiden: Brill.

Beverley, F., \& James, R. A. (1991). The Concept of Love Viewed From a Prototype Perspective. Journal of Personality and Social Psychology, 60(3), 425-438

Blackburn, A. M., Sisemore, T. A., Smith, R. E., \& Re, D. (2012). Hope and forgiveness as mediators of enacted grace in Christians: A survey with implications for psychotherapy. In meeting of the Christian Association for Psychological Studies, Washington, DC.

Boff, L. (1978). Jesus Christ liberator: A critical Christology for our time. Orbis books. Bronte, J. C., \& Wade, J. (2012). The experience of grace: Divine assistance in making a change. Journal of Transpersonal Psychology, 44(2).

Bufford, R. K., McMinn, M. R., Moody, J. A., \& Geczy-Haskins, L. (2018). The effects of grace interventions in church communities. The Journal of Positive Psychology, 13(5), 512-521.

Carmichael, T., \& Cunningham, N. (2017). Theoretical Data Collection and Data Analysis with Gerunds in a Constructivist Grounded Theory Study. Electronic Journal of Business Research Methods, 15(2). 
1 Carter, N., Bryant-Lukosius, D., DiCenso, A., Blythe, J., \& Neville, A. J. (2014, September). The use of triangulation in qualitative research. In Oncology nursing forum (Vol. 41, No. 5).

Catechism of the Catholic Church, $2^{\text {nd }}$ ed., Accessed July 27, 2018, http://www.vatican.va/archive/ENG0015/_P67.HTM

Charmaz, K. (2014). Constructing grounded theory. Sage.

Chiang-Hanisko, L., Newman, D., Dyess, S., Piyakong, D., \& Liehr, P. (2016). Guidance for using mixed methods design in nursing practice research. Applied Nursing Research, 31, 1-5. https://doi.org/10.1016/j.apnr.2015.12.006

Cook, J. D. (2013). Relational Attitudes Conflict Exam (GRACE) Scale: An exploratory factor analysis (Doctoral dissertation). Regent University, Virginia Beach, VA.

Corijn, M. (2017). Religieuze betrokkenheid en leefvormen in het Vlaams Gewest en in Europa. Brussel: Vlaamse Overheid, SVR-Verkenning. Retrieved March 14, 2019 from https://www.statistiekvlaanderen.be/sites/default/files/atoms/files/svrVerkenning-2017-02-religieuze-betrokkenheid.pdf

Coyne, I. (1997). Sampling in qualitative research. Purposeful and theoretical sampling; merging or clear boundaries? Journal of Advanced Nursing, 26(3), 623-630. https://doi.org/10.1046/j.1365-2648.1997.t01-25-00999.x

Cunningham, L. (2003). Grace Can Do More: Spiritual Accompaniment and Spiritual Growth. Cistercian Studies Quarterly, 38(2), 234-236.

De Lubac, H. D. (1946). Surnaturel: études historiques. Parijs.

Denzin, N. K. (1978). The research act: A theoretical introduction to sociological methods. New York: McGraw-Hill.

Dudley, R. L. (1995). Grace, relevancy, and confidence in the future: Why Adventist young adults commit to the church. Journal of Psychology and Christianity.

Egberg Thyme, K., Wiberg, B., Lundman, B., \& Graneheim, U. H. (2013). Qualitative content analysis in art psychotherapy research: Concepts, procedures, and measures to reveal the latent meaning in pictures and the words attached to the pictures. Arts in Psychotherapy, 40(1), 101-107. https://doi.org/10.1016/j.aip.2012.11.007 
1 Elo, S., Kääriäinen, M., Kanste, O., Pölkki, T., Utriainen, K., \& Kyngäs, H. (2014).

Qualitative content analysis: A focus on trustworthiness. SAGE open, 4(1), 158244014522633

Elshout, M., Nelissen, R. M. A., \& Van Beest, I. (2015). A prototype analysis of vengeance. Personal Relationships, 22(3), 502-523. https://doi.org/10.1111/pere.12092

Emmons, R. A., Hill, P. C., Barrett, J. L., \& Kapic, K. M. (2017). Psychological and theological reflections on grace and its relevance for science and practice. Psychology of Religion and Spirituality, 9(3), 276-284. doi:http://dx.doi.org/10.1037/rel0000136

Fehr, B. (1988). Prototype Analysis of the Concepts of Love and Commitment. Journal of Personality and Social Psychology, 55(4), 557-579. https://doi.org/10.1037/0022-3514.55.4.557

Fehr, B., \& Russell, J. A. (1984). Concept of emotion viewed from a prototype perspective. Journal of Experimental Psychology: General, 113, 464-486.

Fehr, B., \& Sprecher, S. (2009). Prototype analysis of the concept of compassionate love. Personal Relationships, 16(3), 343-364. https://doi.org/10.1111/j.1475$\underline{6811.2009 .01227 . \mathrm{x}}$

Finfgeld-Connett, D. (2014). Use of content analysis to conduct knowledge-building and theory-generating qualitative systematic reviews. Qualitative research, 14(3), 341-352.

Fiorenza, F. S., \& Beinert, W. (Eds.). (1995). Handbook of Catholic Theology. Crossroad.Blackburn, A. M., Sisemore, T. A., Smith, R. E., \& Re, D. (2012, March).

Frenz, A. (Ed.). (1975). Grace in Saiva Siddhanta, Vedanta, Islam, and Christianity: Papers Presented at the Seminar Held at Tamil Nadu Theological Seminary, Arasaradi, Madurai, on Saturday, October 11th, 1975. Tamil Nadu Theological Seminary. In

Ganzevoort, R.R. (red.) (1998). De Praxis als Verhaal, Narrativiteit en praktische Theologie. Kampen.

Gentles, S. J., Charles, C., Ploeg, J., \& McKibbon, K. A. (2015). Sampling in qualitative research: Insights from an overview of the methods literature. The Qualitative Report, 20(11), 1772. 
1 Gokcen, N., Hefferon, K., \& Attree, E. (2012). University students' constructions of "flourishing" in British higher education: An inductive content analysis. International Journal of Wellbeing, 2(1), 1-21. https://doi.org/10.5502/ijw.v2i1.1

Golafshani, N. (2003). Understanding reliability and validity in qualitative research. The qualitative report, 8(4), 597-606.

Gowack, P. \& Valle, V. (1998). The experience of feeling grace in voluntary service to the terminally ill. In Valle, R. (Ed.), Phenomenological inquiry in psychology: Existential and transpersonal dimensions (pp. 337-387). Springer Science \& Business Media.

Graves, M. (2014). Gracing Neuroscientific Tendencies of the Embodied Soul. Philosophy and Theology, 26(1), 97-129. https://doi.org/10.5840/philtheol20143125

Graves, M. (2017). Grace and virtue: Theological and psychological dispositions and practices. Psychology of Religion and Spirituality, 9(3), 303-308.

$$
\text { https://doi.org/10.1037/rel0000129 }
$$

Greifeneder, R., Bless, H., \& Pham, M. T. (2011). When Do People Rely on Affective and Cognitive Feelings in Judgment? A Review. Personality and Social Psychology Review, 15(2), 107-141. https://doi.org/10.1177/1088868310367640

Gutierrez, G. (1972). Theologie van de bevrijding. The Netherlands: Baarn.

Hochberg, Y. \& Benjamini, Y. (1990). More powerful procedures for multiple significance testing. Statistics in Medicine. 9 (7): 811-818. doi:10.1002/sim.4780090710. PMID 2218183).

Hsieh, H-F. \& Shannon, S. E. (2005). Three approaches to qualitative content analysis. Qualitative Health Research, 15, 1277-1288. http://dx.doi.org/10.1177/1049732305276687

James, W. (1902). The varieties of religious experience. New York: Longmans, Green

Jick, T. D. (1979). Mixing qualitative and quantitative methods: Triangulation in action. Administrative science quarterly, 24(4), 602-611.

Johnson, B. R. (1997). Examining the validity structure of qualitative research. Education, 118(3), 282-292.

Lacoste., Riaudel, O. \& Beauchamp, P. (2007). Dictionnaire critique de théologie. Paris: Presses universitaires de France.

Lamberts, K. (2013). Knowledge concepts and categories. Psychology Press. 
1 Levitt, H. M., Bamberg, M., Creswell, J. W., Frost, D. M., \& Suárez-Orozco, C. (2018). Journal Article Reporting Standards for Qualitative Primary, Qualitative MetaAnalytic and Mixed Methods Research in Psychology: The APA Publications and Communications Board Task Force Report, 73(1), 26-46.

Luna, L. M. R., Van Tongeren, D. R., \& Witvliet, C. V. O. (2017). Virtue, positive psychology, and religion: Consideration of an overarching virtue and an underpinning mechanism. Psychology of Religion and Spirituality, 9(3), 299-302. https://doi.org/10.1037/rel0000127

MacLachlan, B. (1993). The Age of Grace: Charis in Early Greek Poetry. Princeton, NJ: Princeton UP.

Marks, Darren C. (2010). The mind under grace: Why theology is an essential nutrient for spiritual growth.(Cover story). Christianity Today, 54(3), 22.

McGinnis, J., \& Mortellaro, E. (2011). Grace and Christian psychology-

Pt. 1: Preliminary measurement, relationships, and implications for practice. Edification: The Transdisciplinary Journal of Christian Psychology, 4, 57-63.

McMinn, M. R. (2010). Sin and grace in Christian counseling: An integrative paradigm. InterVarsity Press.

McMinn, M. R., Ruiz, J. N., Marx, D., Wright, J. B., \& Gilbert, N. B. (2006). Professional psychology and the doctrines of sin and grace: Christian leaders' perspectives. Professional Psychology: Research and Practice, 37(3), 295-302. https://doi.org/10.1037/0735-7028.37.3.295

Meissner, W. W. (1966). Foundations for a psychology of grace. USA: Paulist Press.

Murray, J. (1884). A new English dictionary on historical principles. Oxford: Clarendon.

New catholic encyclopedia. (1967). New York (N.Y.): MacGraw-Hill.

Patrick, S., Beckenbach, J., Sells, J., \& Reardon, R. F. (2013). An empirical investigation into justice, grace, and forgiveness: Paths to relationship satisfaction. The Family Journal, 21(2), 146-153.

Payton, J. T., Spradlin, J. D., \& Bufford, R. K. (2000, March). A measure of grace: Preliminary development of a grace scale. Paper presented at the Christian Association for Psychological Studies annual meetings, Tulsa, OK. 
1 Pearson, K. (1900). On the criterion that a given system of deviations from the probable in the case of a correlated system of variables is such that it can be reasonably supposed to have arisen from random sampling. Philosophical Magazine. Series 5. 50 (302): 157-175. doi:10.1080/14786440009463897.).

Peristiany, J. G., \& Pitt-Rivers, J. (Eds.). (2005). Honor and grace in anthropology (Vol. 76). Cambridge University Press.

Planalp, S., \& Fitness, J. (1999). Thinking/Feeling about Social and Personal Relationships. Journal of Social and Personal Relationships, 16(6), 731-750. https://doi.org/10.1177/0265407599166004

Rahner, K. (1954). Über das Verhältnis von Natur und Gnade. Schriften zur Theologie, 1, 323-345.

Richardson, F. C., \& Guignon, C. B. (2008). Positive psychology and philosophy of social science. Theory \& Psychology, 18(5), 605-627.

Rogers, Carl R. Client-centered Therapy: Its Current Practice, Implications and Theory. Boston: Houghton Mifflin, 1951.

Rogers, J. R., \& Soyka, K. M. (2004). Grace and Compassion at “Ground Zero," New York City. Crisis, 25(1), 27-29.

Ruch, W., \& Proyer, R. T. (2015). Mapping strengths into virtues: The relation of the 24 VIA-strengths to six ubiquitous virtues. Frontiers in Psychology, 6 (MAR), 1-12. https://doi.org/10.3389/fpsyg.2015.00460

Saldaña, J., 2016. The coding manual for qualitative researchers. Thousand Oaks, CA: Sage. https://doi.org/10.1017/CBO9781107415324.004

Savin-Baden, M., \& Major, C. H. (2013). Qualitative research: The essential guide to theory and practice. Routledge.

Schillebeeckx, E. (1977). Gerechtheid en Liefde, Genade en Bevrijding. Bloemendaal.

Schnitker, S. A., \& Emmons, R. A. (2017). The Psychology of Virtue : Integrating Positive Psychology and the Psychology of Religion, 9(3), 239-241.

Schoonenberg, P. (1961). De Erfzonde als Situatie. Bijdragen, 22(1), 1-30.

Segundo, J.L. (1980). Grace and the Human Condition, a Theology for a New Humanity. Dublin.

Seligman, M. E., \& Csikszentmihalyi, M. (2000). Positive psychology: An introduction (Vol. 55, No. 1, p. 5). American Psychological Association. 
1 Sells, J. N., Beckenbach, J., \& Patrick, S. (2009). Pain and defense versus grace and justice: The relational conflict and restoration model. The Family Journal, 17(3), 203-212.

Sisemore, T. A., Arbuckle, M., Killian, M., Mortellaro, E., Swanson, M., Fisher, R., \& McGinnis, J. (2011). Grace and Christian Psychology-Part 1: Preliminary Measurement, Relationships, and Implications for Practice. Edification: The Transdisciplinary Journal of Christian Psychology, 4(2).

Spradlin, J. D. (2002). Shame, grace, and spirituality: A comparison of measures (Doctoral dissertation). George Fox University, Newberg OR.

Spuybroek, L. (2014). Charis and Radiance: The Ontological Dimensions of Beauty. In S. Van Tuinen (ed.), Giving and Taking: Antidotes to a Culture of Greed (pp. 119 - 149). Rotterdam: nai010.

Statbel (2017). Onderwijsniveau van de Belgische bevolking vanaf 15 jaar en ouder 2017. Retrieved March 14, 2019 from https://statbel.fgov.be/nl/themas/werkopleiding/opleidingen-en-onderwijs/onderwijsniveau\#figures

The Catholic Encyclopedia (1909), vol.6, Retrieved March 6, 2018 from New Advent: http://www.newadvent.org/cathen/06689a.htm

Vacant, A., Mangenot, E. \& Amann, E. (1930). Dictionnaire de théologie catholique : Contenant l'exposé des doctrines de la théologie catholique, leurs preuves et leur histoire (3e tirage 1930 ed.). Paris: Letouzey et Ané.

Vaismoradi, M., Turunen, H., \& Bondas, T. (2013). Content analysis and thematic analysis: Implications for conducting a qualitative descriptive study. Nursing and Health Sciences, 15(3), 398-405. https://doi.org/10.1111/nhs.12048

Versteegen T.J.M. (2013). Geleefde genade. Een bijdrage aan de theologie van genade vanuit ervaringen van katholieke vrouwen. Gorinchem : Narratio.

Wahking, H. (1992). Spiritual growth through grace and forgiveness. Journal of Psychology and Christianity.

Ward, K. (1998). Religion and human nature. Oxford, England: Clarendon Press. http://dx.doi.org/10.1093/acprof:oso/9780198269618.001.0001

Watson, P. J., Chen, Z., \& Sisemore, T. A. (2011). Grace and Christian psychology-Pt. 2: Psychometric refinements and relationships with self-compassion, depression, beliefs about sin, and religious orientation. Edification: The Transdisciplinary Journal of Christian Psychology, 4, 64-72. 
1 Watson, P. J., Hood, R. W., Jr., Morris, R. J., \& Hall, J. R. (1985).

2

Religiosity, sin, and self-esteem. Journal of Psychology and Theology, 13, 116-128.

3 Watson, P. J., Morris, R. J., \& Hood, R. W., Jr. (1988a). Sin and self-functioning,

4

Pt. 1: Grace, guilt, and self-consciousness. Journal of Psychology and Theology, 16,

5 254-269.

6 Watson, P. J., Morris, R. J., \& Hood, R. W., Jr. (1988b). Sin and self-functioning, Pt. 2: Grace, guilt, and psychological adjustment. Journal of Psychology and Theology, 16, 270-281.

9 Wetzel, J. (1992). Augustine and the Limits of Virtue. Cambridge University Press.

10 Worthington, E. L., \& Williams, D. R. (2015). Forgiveness and Health. https://doi.org/10.1007/978-94-017-9993-5

12 Zhang, Y., \& Wildemuth, B. M. (2009). Qualitative Analysis of Content. Applications of Social Research Methods to Questions in Information and Library Science, 421. https://doi.org/10.1002/hbm.20661 


\section{Appendices}

4 Deze vragenlijst is deel van een groter project rondom het beschrijven van begrippen. In

5 deze studie zijn we in het bijzonder geïnteresseerd in wat mensen onder de term

6 GENADE verstaan..

7 Wanneer men bv. gevraagd wordt om kenmerken van avontuurlijk op te lijsten, kan

8 men schrijven: interessant, gedurfd, spannend,...

9 Het concept waar wij geïnteresseerd in zijn is GENADE.

10 Wilt $\mathrm{u}$ alsjeblieft zoveel mogelijk kenmerken van genade opsommen die in u opkomen.

11 Deze kenmerken kunnen gaan over typische elementen, onderdelen, facetten, gevoelens,

12 ideeën of gedragingen,... alles dat kan helpen om GENADE te definiëren.

13 Denk eraan dat er geen juiste of foute antwoorden zijn, het gaat om zoveel mogelijk

14 kenmerken op te sommen die spontaan in u opkomen, maar besteed er ook niet meer 15 aan dan drie minuten.

17 (translation in English)

18 This questionnaire is part of a larger project on the description of concepts.

19 In this study we are particularly interested in what people mean by the word GRACE.

20 For example, when one is asked to list characteristics of adventurous, one can write:

21 interesting, daring, exciting, ...

22 The concept that we are interested in is GRACE.

23 Please list as many characteristics of grace as come to mind. These characteristics can 24 be about typical elements, parts, facets, feelings, ideas or behaviors, anything that can 25 help to define GRACE. Remember that there are no right or wrong answers, it is about 26 enumerating as many features as possible that spontaneously occur to you, but do not 27 spend more than three minutes on listing them. 


\begin{tabular}{|c|c|c|c|}
\hline $\begin{array}{l}\text { VIA- virtues and } \\
\text { strengths of character }\end{array}$ & $\begin{array}{c}\text { Aquinas } \\
\text { on ethical living }{ }^{\mathrm{b}}\end{array}$ & $\begin{array}{l}\text { Gifts of the } \\
\text { Holy Spirit }\end{array}$ & $\begin{array}{l}\text { Fruits of the } \\
\text { Holy Spirit }\end{array}$ \\
\hline Wisdom \& knowledge & Theological virtue & wisdom & charity \\
\hline creativity & faith & understanding & joy \\
\hline curiosity & hope & counsel & peace \\
\hline open-mindedness & charity & fortitude & patience \\
\hline love of learning & Intellectual virtue & knowledge & kindness \\
\hline perspective & prudence & piety & goodness \\
\hline Courage & Moral virtues & fear of the Lord & longanimity \\
\hline authenticity & Justice & & gentleness \\
\hline bravery & religion & & faith \\
\hline persistence & piety & & modesty \\
\hline zest & observance & & Self-control \\
\hline Humanity & obedience & & chastity \\
\hline kindness & gratitude & & \\
\hline love & vengeance & & \\
\hline social intelligence & truth & & \\
\hline justice & affability & & \\
\hline fairness & liberality & & \\
\hline leadership & epikeia & & \\
\hline
\end{tabular}


teamwork

Temperance

forgiveness

modesty

prudence

self-regulation

\section{Transcendence}

appreciation of beauty and excellence

gratitude

hope

humor

spirituality

\section{Fortitude}

martyrdom

magnanimity

magnificence

patience

perseverance

\section{Temperance}

spiritual beauty

abstinence

sobriety

chastity

virginity

continence

clemency

meekness

modesty

humility

studiousness

1 a character strength in bold, accompanying virtues listed below

2 b division in bold, subdivion in italic, accompanying virtues listed below 


\section{$1 \quad$ Table 1}

2 Overview of codes, categories, themes and theoretical building blocks

3

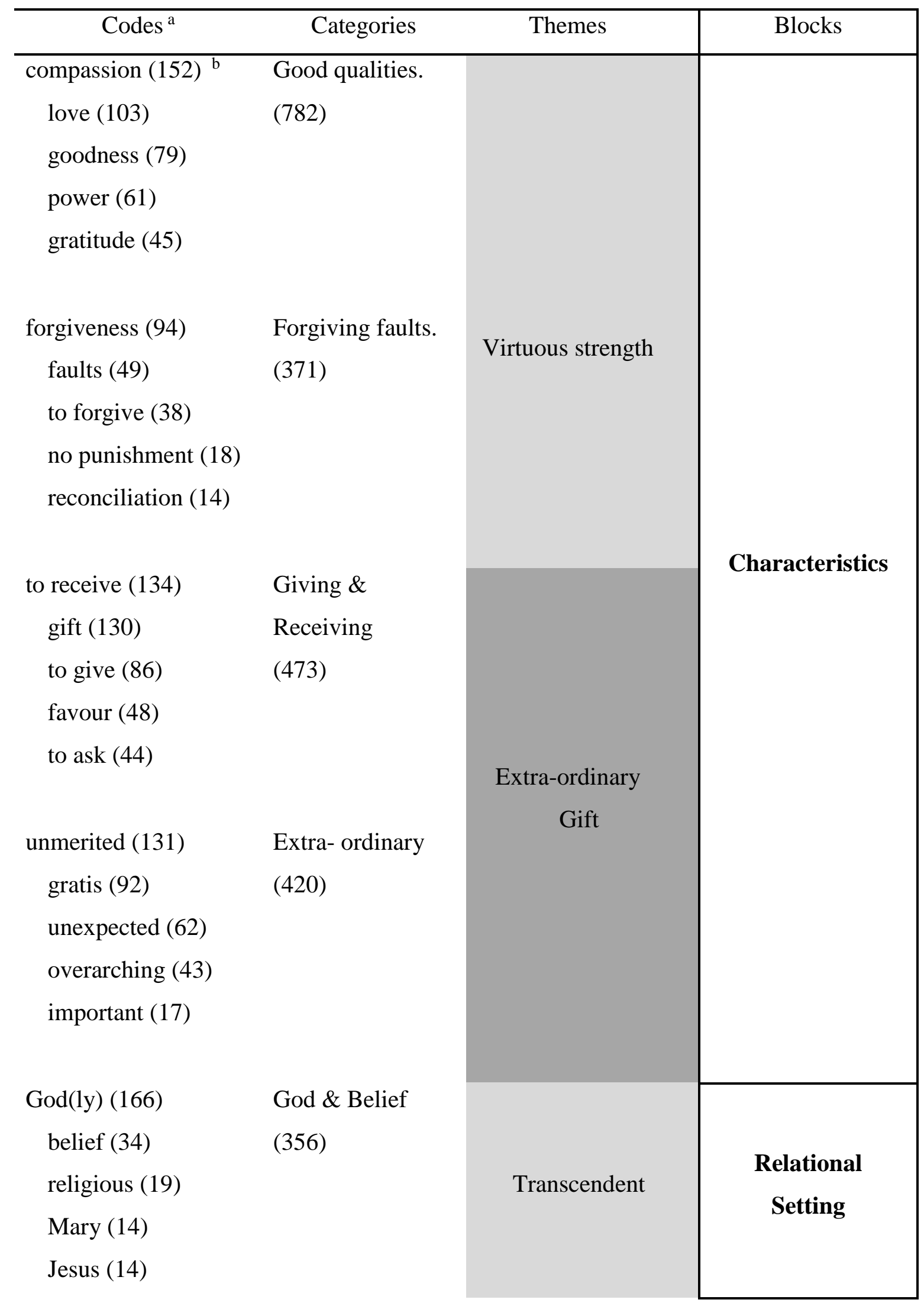




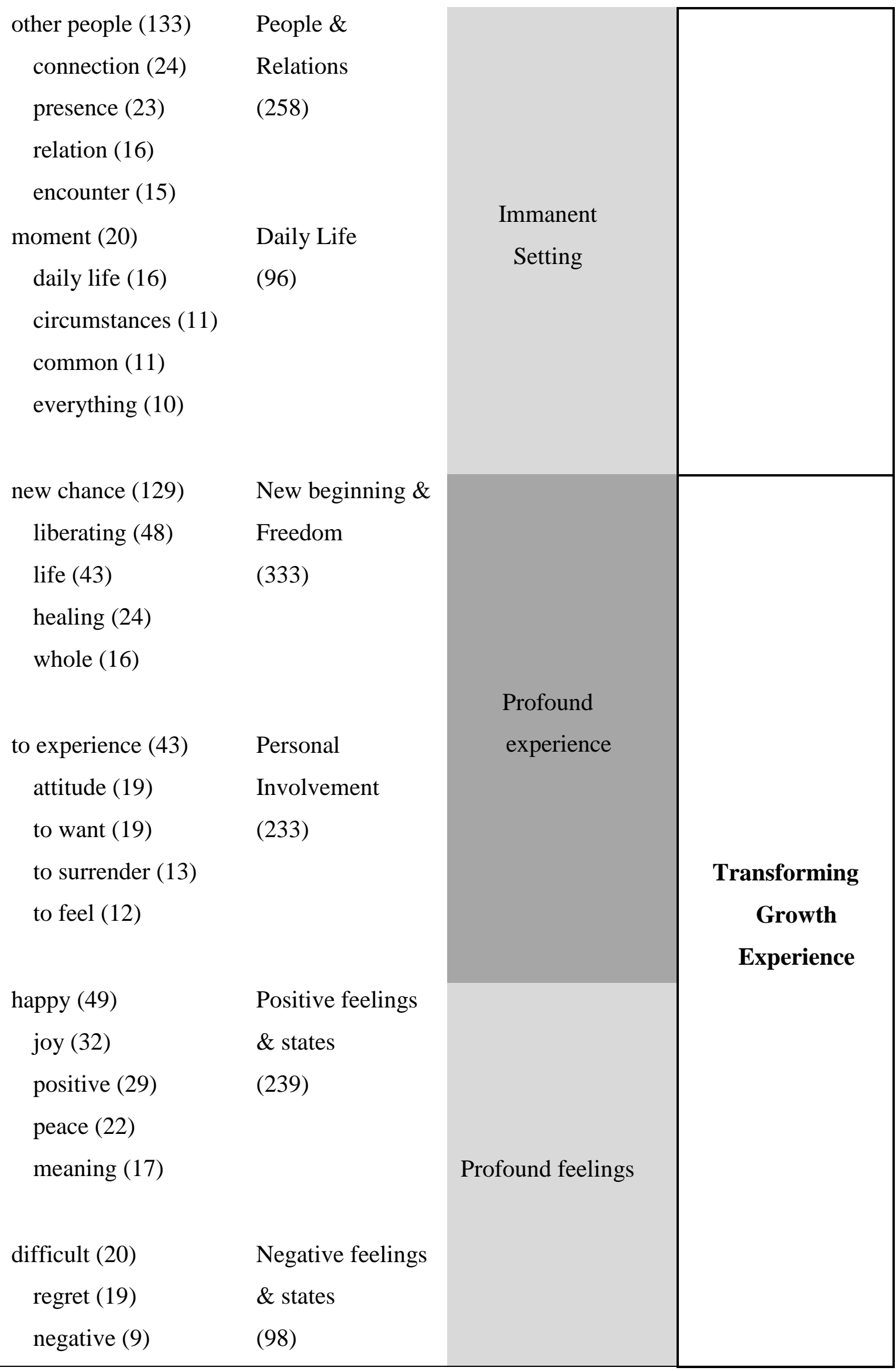


revenge (6)

sadness (5)

1

$2{ }^{a}$ five most used codes for each category

$3{ }^{b}$ in brackets, you find the number of references coded for the accompanying keyword

4 or category

5 


\section{$1 \quad$ Table 2}

2 Lay understanding of grace: Categories for each theme with example quote

3

\begin{tabular}{|c|c|}
\hline Themes with their categories & Example quote $^{\mathrm{a}}$ \\
\hline \multicolumn{2}{|l|}{ Virtuous qualities } \\
\hline Good qualities & $\begin{array}{l}\text { "to be understood, to get help, friends, } \\
\text { strength, happiness, energy } \\
\text { appreciation, to be able to, to be } \\
\text { accepted, getting support, to persevere, } \\
\text { creativity" }\end{array}$ \\
\hline Forgiving Faults & $\begin{array}{l}\text { "to show grace is to show understanding } \\
\text { for the situation of the other - after the } \\
\text { other has wronged you, to show } \\
\text { compassion, possibly to forgive, to no } \\
\text { longer blame the abuser for doing } \\
\text { something that you experienced as } \\
\text { negative" }\end{array}$ \\
\hline \multicolumn{2}{|l|}{ Extra-ordinary gift } \\
\hline Giving \& Receiving & $\begin{array}{l}\text { "Grace is: gift, which one just receives, } \\
\text { from God or from others, which one } \\
\text { has not deserved, sometimes one does } \\
\text { cooperate with grace, but grace is } \\
\text { nevertheless given as a 'gratuitous gift'. } \\
\text { For example, even when one has made } \\
\text { mistakes, falls short, and may } \\
\text { experience that the other or God is } \\
\text { 'merciful', continues to believe in you } \\
\text { despite everything." }\end{array}$ \\
\hline Extra-ordinary & $\begin{array}{l}\text { "free, depending on someone, amazing, } \\
\text { incredible, unusual, nothing can be } \\
\text { added or ehanced, grace comes from } \\
\text { one side but can also be refused by the } \\
\text { gifted person, the one who receives }\end{array}$ \\
\hline
\end{tabular}


grace does not have to do anything for it"

Setting Transcendent \& Immanent

God \& Belief

People \& Relations

Daily life

Profound experience
"God's grace, gratuitous, unmerited, gift, gifted, grateful, for everyone who wants to notice. God also gives grace if you don't know it yourself. Trust prior to knowledge. Abundance - there is never enough grace, there is always more. Gentleness, forgiveness."

"Grace is given to you. The realization that you are part of a greater whole. Grace is the awareness that life is given to you. Grace is the power to be able to live life as it is, meeting people who carry you. Grace is love, power, affection, courage and strength."

"Moments when everything coincides and feels good, not complaining too much about setbacks, good health, where your cradle is and being lucky that it is in Belgium, not having financial shortfalls"

"The life that s miles on us. Or being in dark conditions, but deep in your heart knowing that there will be a solution. Fundamental trust. A certainty that God carries you and Mary, who stood under the cross, holds you by the hand. So grace is a positive surprise, a source of joy, unforeseen encounters.

Optimism! Grace is the life adventure, 
even if you sometimes doubt whether you made the right decision."

New Beginning \& Freedom

"free, costless, not deserved, gives peace and joy, relief, works liberating"

Personal Involvement

"Forgiveness, release, liberation and being able to start again. Grace requires the ability to love unconditionally and to be empathetic. Courage and inner strength to choose grace.”

Profound Feelings

Positive Feelings \& States "free, without obligation, given, not entitled to, always positive, gentle, strong, self-empowering, righting, persevering, forgiving, encouraging, growth-enhancing, giving joy, giving peace"

Negative Feelings \& States

“to beg, regret, religious, hope, oldfashioned, kneel, asking, sadness, emotion, lost, desperate, fate, judge, justice, merciless, forgiveness, perpetrator, victim, grace"

$1 \quad{ }^{a}$ English translation of original Dutch description of grace 
Table 3

2 Z-scores $>1 S D$ of the grand mean for the virtue rating

3

\begin{tabular}{|c|c|c|c|}
\hline \multirow[t]{4}{*}{ Virtues } & Z- & Virtues & Z- \\
\hline & score & & score \\
\hline & $>+1$ & & $<-1$ \\
\hline & SD & & SD \\
\hline Forgiveness & 2.26 & Prudence & -1.04 \\
\hline Love & 2.10 & Teamwork & -1.04 \\
\hline Humanity & 1.74 & Obedience & -1.10 \\
\hline Goodness & 1.57 & Modesty & -1.10 \\
\hline Magnanimity & 1.53 & $\begin{array}{l}\text { Love of } \\
\text { Learning }\end{array}$ & -1.11 \\
\hline Peace & 1.30 & Observance & -1.14 \\
\hline Hope & 1.20 & Martyrdom & -1.36 \\
\hline \multirow[t]{5}{*}{ Gratitude } & 1.13 & Chastity & -1.46 \\
\hline & & Abstinence & -1.47 \\
\hline & & Curiosity & -1.52 \\
\hline & & Virginity & -2.08 \\
\hline & & Vengeance & -2.50 \\
\hline
\end{tabular}




\section{Table 4}

Results of Pearson's chi-squared test $\left(\chi^{2}\right)$ examining difference in amount of coding for age groups

\begin{tabular}{|c|c|c|c|c|c|c|c|c|c|c|}
\hline \multirow[t]{3}{*}{ Categories } & \multirow{2}{*}{\multicolumn{2}{|c|}{$\begin{array}{l}\text { Age 18-39 } \\
n^{a}=136\end{array}$}} & \multirow{2}{*}{\multicolumn{2}{|c|}{$\begin{array}{c}\text { Age } 40-64 \\
n=215\end{array}$}} & \multirow{2}{*}{\multicolumn{2}{|c|}{$\begin{array}{l}\text { Age } 65+ \\
n=105\end{array}$}} & \multirow{2}{*}{\multicolumn{2}{|c|}{$\begin{array}{c}\text { Total Sample } \\
\mathrm{N}=456\end{array}$}} & \multirow{3}{*}{$\chi^{2}$} & \multirow{3}{*}{$p$} \\
\hline & & & & & & & & & & \\
\hline & $n^{b}$ & $\%$ & $n$ & $\%$ & $n$ & $\%$ & $n$ & $\%$ & & \\
\hline Good Qualities & 91 & 66.91 & 153 & 71.16 & 70 & 66.67 & 314 & 68.86 & 1.0080 & 0.604 \\
\hline Forgiving faults & 101 & 74.26 & 101 & 46.98 & 37 & 35.24 & 239 & 52.41 & 41.0019 & $0.000 * * *$ \\
\hline Extra-Ordinary & 41 & 30.15 & 110 & 51.16 & 56 & 53.33 & 207 & 45.39 & 18.3110 & $0.000 * * *$ \\
\hline Giving \& Receiving & 69 & 50.74 & 122 & 56.74 & 61 & 58.1 & 252 & 55.26 & 1.6592 & 0.436 \\
\hline Transcendent & 45 & 33.09 & 95 & 44.19 & 49 & 46.67 & 189 & 41.45 & 5.7589 & 0.056 \\
\hline People \& Relations & 34 & 25 & 67 & 31.16 & 40 & 38.1 & 141 & 30.92 & 4.7682 & 0.092 \\
\hline Daily Life & 7 & 5.15 & 32 & 14.88 & 22 & 20.95 & 61 & 13.38 & 13.5706 & $0.001 * *$ \\
\hline New beginning \& Freedom & 43 & 31.62 & 87 & 40.47 & 42 & 40 & 172 & 37.72 & 3.0779 & 0.215 \\
\hline Personal Involvement & 21 & 15.44 & 60 & 27.91 & 50 & 47.62 & 131 & 28.73 & 30.0980 & $0.000 * * *$ \\
\hline Positive Feelings & 34 & 25 & 75 & 34.88 & 44 & 41.9 & 153 & 33.55 & 7.9182 & 0.019 \\
\hline Negative Feelings & 31 & 22.79 & 26 & 12.09 & 14 & 13.33 & 71 & 15.57 & 7.7759 & 0.020 \\
\hline
\end{tabular}

Note. Degree of freedom $=2 . * \mathrm{p}<0.05 * * \mathrm{p}<0.01 * * * \mathrm{p}<0.001$ after FDR

${ }^{a} \mathrm{n}$ indicates the sample size of the different age groups

${ }^{\mathrm{b}} \mathrm{n}$ indicates how many participants used the category in their description of grace 


\section{Table 5}

Results of Pearson's chi-squared test $\left(\chi^{2}\right)$ examining difference in amount of coding for gender

\begin{tabular}{|c|c|c|c|c|c|c|c|c|}
\hline \multirow[t]{3}{*}{ Categories } & \multirow{2}{*}{\multicolumn{2}{|c|}{$\begin{array}{c}\text { Male } \\
\mathrm{n}^{\mathrm{a}}=162\end{array}$}} & \multirow{2}{*}{\multicolumn{2}{|c|}{$\begin{array}{l}\text { Female } \\
n=291\end{array}$}} & \multirow{2}{*}{\multicolumn{2}{|c|}{$\begin{array}{c}\text { Total Sample } \\
\mathrm{N}=453^{\mathrm{b}}\end{array}$}} & \multirow{3}{*}{$\chi^{2}$} & \multirow{3}{*}{$p$} \\
\hline & & & & & & & & \\
\hline & $n^{c}$ & $\%$ & $n$ & $\%$ & $n$ & $\%$ & & \\
\hline Good Qualities & 99 & 61.11 & 213 & 73.2 & 312 & 68.87 & 7.089 & $0.008 *$ \\
\hline Forgiving faults & 76 & 46.91 & 160 & 54.98 & 236 & 52.10 & 2.715 & 0.099 \\
\hline Extra-Ordinary & 81 & 50 & 124 & 42.61 & 205 & 45.25 & 2.293 & 0.130 \\
\hline Giving \& Receiving & 87 & 53.7 & 164 & 56.36 & 251 & 55.41 & 0.297 & 0.586 \\
\hline Transcendent & 71 & 43.83 & 116 & 39.86 & 187 & 41.28 & 0.675 & 0.411 \\
\hline People \& Relations & 49 & 30.25 & 89 & 30.58 & 138 & 30.46 & 0.006 & 0.940 \\
\hline Daily Life & 20 & 12.35 & 40 & 13.75 & 60 & 13.25 & 0.178 & 0.674 \\
\hline New Beginning \& Freedom & 58 & 35.8 & 112 & 38.49 & 170 & 37.53 & 0.320 & 0.572 \\
\hline Personal Involvement & 45 & 27.78 & 84 & 28.87 & 129 & 28.48 & 0.061 & 0.806 \\
\hline Positive Feelings & 54 & 33.33 & 97 & 33.33 & 151 & 33.33 & 0.000 & 1.000 \\
\hline Negative Feelings & 27 & 16.67 & 43 & 14.78 & 70 & 15.45 & 0.285 & 0.594 \\
\hline
\end{tabular}

Note. Degree of freedom $=1 . * \mathrm{p}<0.05-* * \mathrm{p}<0.01-* * * \mathrm{p}<0.001$ after FDR

${ }^{a} \mathrm{n}$ indicates the sample size of male/female participants

${ }^{\mathrm{b}} 3$ participants identified as non-binary giving 456-3

${ }^{\mathrm{c}} \mathrm{n}$ indicates how many participants used the category in their description of grace 


\section{Table 6}

Results of Pearson's chi-squared test $\left(\chi^{2}\right)$ examining difference in amount of coding for reported belief

\begin{tabular}{|c|c|c|c|c|c|c|c|c|}
\hline \multirow[t]{3}{*}{ Categories } & \multirow{2}{*}{\multicolumn{2}{|c|}{$\begin{array}{l}\text { Believing } \\
\mathrm{n}^{\mathrm{a}}=326\end{array}$}} & \multirow{2}{*}{\multicolumn{2}{|c|}{$\begin{array}{c}\text { Non-believing } \\
\mathrm{n}=51\end{array}$}} & \multirow{2}{*}{\multicolumn{2}{|c|}{$\begin{array}{c}\text { Total Sample } \\
\mathrm{N}=377^{\mathrm{b}}\end{array}$}} & \multirow{3}{*}{$\chi^{2}$} & \multirow{3}{*}{$p$} \\
\hline & & & & & & & & \\
\hline & $n^{c}$ & $\%$ & $n$ & $\%$ & $n$ & $\%$ & & \\
\hline Good Qualities & 226 & 69.33 & 34 & 66.67 & 260 & 68.97 & 0.146 & 0.703 \\
\hline Forgiving Faults & 142 & 43.56 & 44 & 86.27 & 186 & 49.34 & 32.194 & $0.000 * * *$ \\
\hline Extra-Ordinary & 170 & 52.15 & 11 & 21.57 & 181 & 48.01 & 16.521 & $0.000 * * *$ \\
\hline Giving \& Receiving & 195 & 59.82 & 22 & 43.14 & 217 & 57.56 & 5.022 & 0.025 \\
\hline Transcendent & 157 & 48.16 & 14 & 27.45 & 171 & 45.36 & 7.631 & $0.006^{*}$ \\
\hline People \& Relations & 103 & 31.6 & 19 & 37.25 & 122 & 32.36 & 0.645 & 0.422 \\
\hline Daily Life & 51 & 15.64 & 3 & 5.88 & 54 & 14.32 & 3.424 & 0.064 \\
\hline New beginning \& Freedom & 127 & 38.96 & 19 & 37.25 & 146 & 38.73 & 0.054 & 0.816 \\
\hline Personal Involvement & 107 & 32.82 & 9 & 17.65 & 116 & 30.77 & 4.767 & 0.029 \\
\hline Positive Feelings & 127 & 38.96 & 5 & 9.8 & 132 & 35.01 & 16.473 & $0.000 * * *$ \\
\hline Negative Feelings & 46 & 14.11 & 13 & 25.49 & 59 & 15.65 & 4.326 & 0.038 \\
\hline
\end{tabular}

Note. Degree of freedom $=1 . * \mathrm{p}<0.05-* * \mathrm{p}<0.01-* * * \mathrm{p}<0.001$ after FDR

${ }^{a} \mathrm{n}$ indicates the sample size of believing and non-believing participants

${ }^{\mathrm{b}} \mathrm{N}<$ total sample of this study because not all participants completed all socio-demographics

${ }^{\mathrm{c}} \mathrm{n}$ indicates how many participants used the category in their description of grace 


\section{Table 7}

Results of Pearson's chi-squared test $\left(\chi^{2}\right)$ examining difference in amount of coding for reported religious activity

\begin{tabular}{|c|c|c|c|c|c|c|c|c|}
\hline \multirow[t]{3}{*}{ Categories } & \multirow{2}{*}{\multicolumn{2}{|c|}{$\begin{array}{c}\text { Active } \\
\mathrm{n}^{\mathrm{a}}=214\end{array}$}} & \multirow{2}{*}{\multicolumn{2}{|c|}{$\begin{array}{l}\text { Non or limited active } \\
\qquad \mathrm{n}=145\end{array}$}} & \multirow{2}{*}{\multicolumn{2}{|c|}{$\begin{array}{c}\text { Total Sample } \\
\mathrm{N}=395^{\mathrm{b}}\end{array}$}} & \multirow{3}{*}{$\chi^{2}$} & \multirow{3}{*}{$p$} \\
\hline & & & & & & & & \\
\hline & $n^{c}$ & $\%$ & $n$ & $\%$ & $n$ & $\%$ & & \\
\hline Good Qualities & 148 & 69.16 & 99 & 68.28 & 247 & 68.8 & 0.031 & 0.859 \\
\hline Forgiving faults & 79 & 36.92 & 107 & 73.79 & 186 & 51.81 & 47.080 & $0.000 * * *$ \\
\hline Extra-Ordinary & 133 & 62.15 & 34 & 23.45 & 167 & 46.52 & 52.037 & $0.000 * * *$ \\
\hline Giving \& Receiving & 146 & 68.22 & 57 & 39.31 & 203 & 56.55 & 29.408 & $0.000 * * *$ \\
\hline Transcendent & 107 & 50 & 47 & 32.41 & 154 & 42.9 & 10.913 & $0.001 * *$ \\
\hline People \& Relations & 70 & 32.71 & 48 & 33.1 & 118 & 32.87 & 0.006 & 0.938 \\
\hline Daily Life & 36 & 16.82 & 11 & 7.59 & 47 & 13.09 & 6.481 & 0.011 \\
\hline New beginning \& Freedom & 89 & 41.59 & 47 & 32.41 & 136 & 37.88 & 3.092 & 0.079 \\
\hline Personal Involvement & 77 & 35.98 & 35 & 24.14 & 112 & 31.2 & 5.648 & 0.017 \\
\hline Positive Feelings & 93 & 43.46 & 31 & 21.38 & 124 & 34.54 & 18.635 & $0.000 * * *$ \\
\hline Negative Feelings & 23 & 10.75 & 31 & 21.38 & 54 & 15.04 & 7.645 & $0.006^{*}$ \\
\hline
\end{tabular}

Note. Degree of freedom $=1 . * \mathrm{p}<0.05-* * \mathrm{p}<0.01-* * * \mathrm{p}<0.001$ after FDR

${ }^{a} \mathrm{n}$ indicates the sample size of active and non or limited active participants

${ }^{b} \mathrm{~N}<$ total sample of this study because not all participants completed all socio-demographics

${ }^{\mathrm{c}} \mathrm{n}$ indicates how many participants used the category in their description of grace 


\section{Figures}

\section{Figure 1}

Saldana's (2016, p.14) streamlined codes-to-theory model for qualitative inquiry

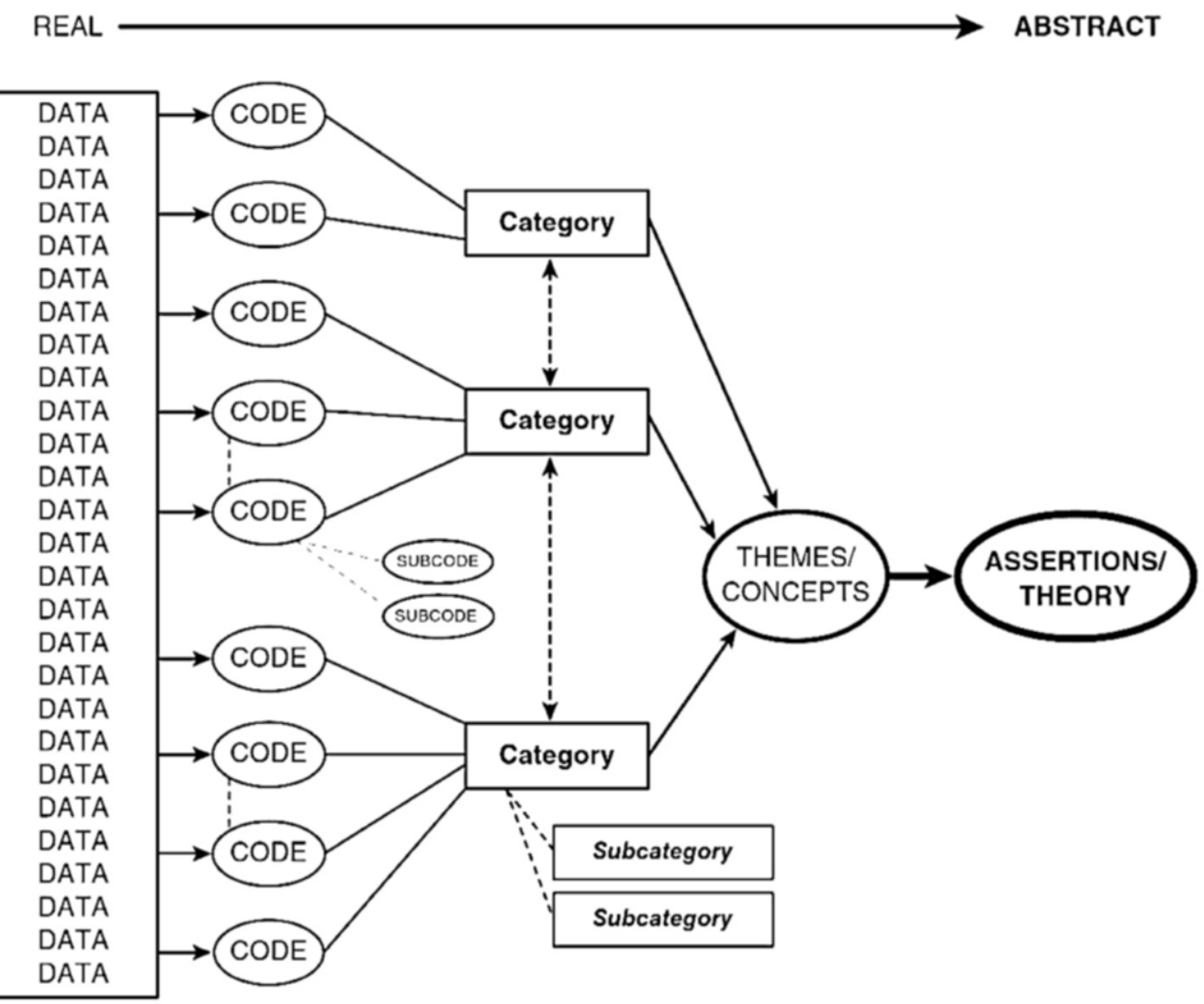




\section{Figure 2}

Coding counts for the 'Listing Grace' study

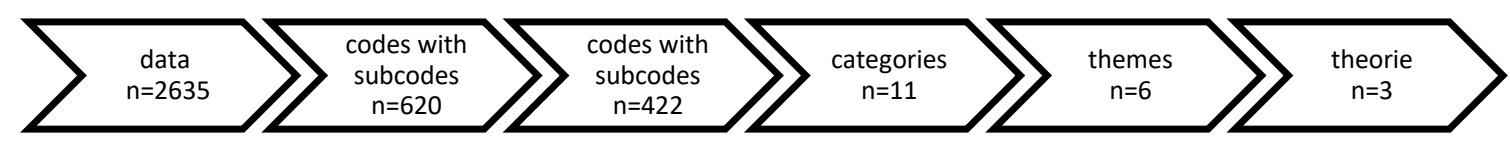




\section{Figure 3}

Visualization of the emerging lay conceptualization of grace based on the reported quantitative and qualitative content analysis of 456 lay descriptions of grace

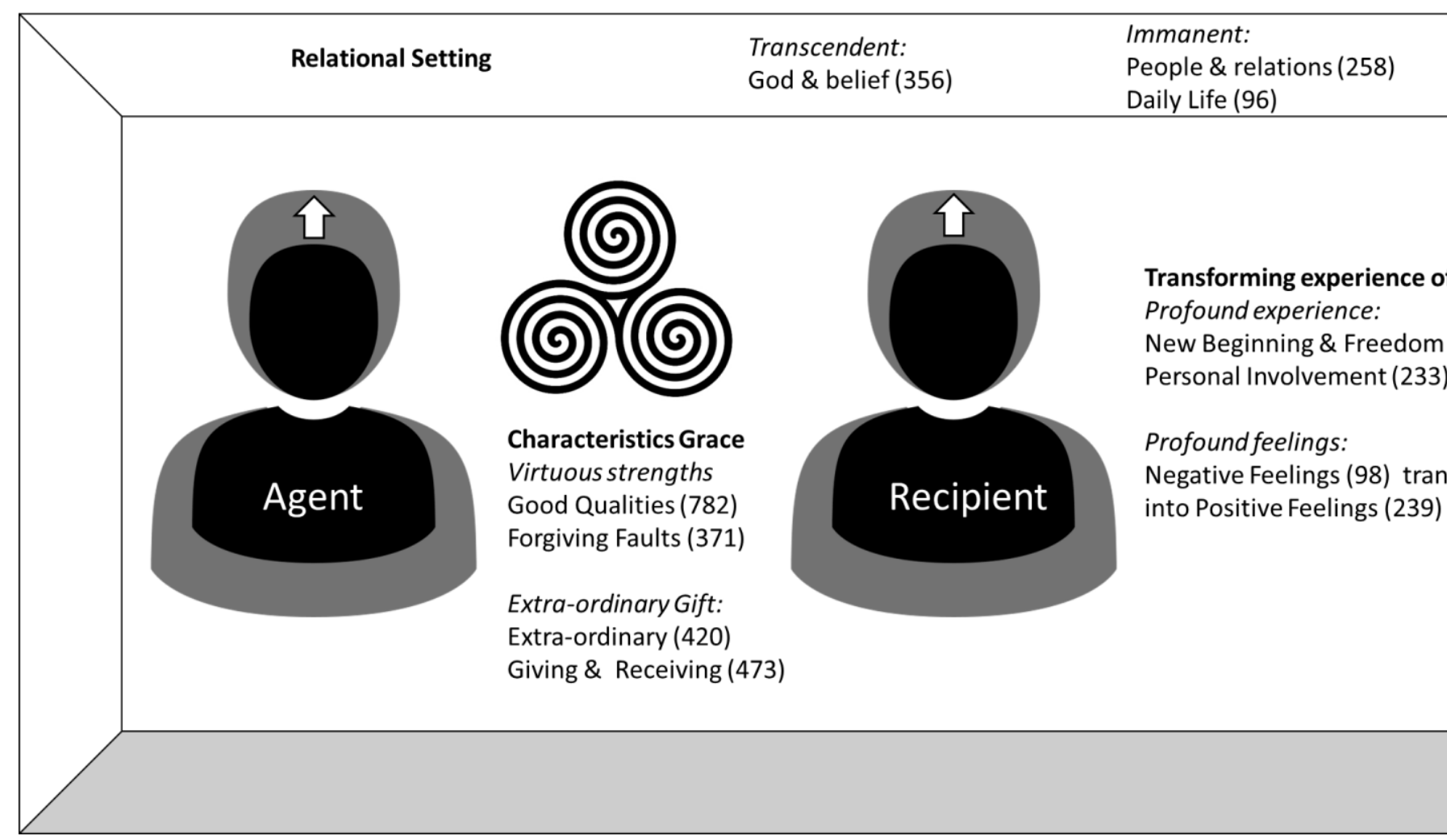

Note. The number of codes per category is given in brackets. Themes are displayed in bold. 